\title{
IMPLEMENTASI PEMBELAJARAN SAINS UNTUK ANAK USIA DINI DALAM MENGHADAPI MASYARAKAT EKONOMI ASEAN (MEA)
}

\author{
Sigit Prasetyo \\ Prodi PGMI (Pendidikan Guru Madrasah Ibtadiiyah) \\ UIN Sunan Kalijaga Yogyakarta \\ Email : siepras@yahoo.co.id
}

\begin{abstract}
Science learning is a lifelong learning process as learning to count. Children of all ages will get benefit by analyzing their surrounding circumstances that had the element of science. Children need to be encouraged in order to gain more scientific experience in the nature, then to explain the events they saw, ask, and analyze bow the events occurred. Implementation of science learning for early childhood in facing the $M E A$ is to include six basic skills of science into four determinants factor of a country's progress, the namely is innovation, mastery network through communication, the mastery of technology, and the wealth of natural resources. The six basic skills of science that need to be taught to students are: observation, communication, classification, measurement, inference, and forecasting (prediction). Those six skills integrate over when a child doing simple experiment. The six basic skills above are very important as an independent skills as important as an integrated skills. The skills honed from an early age are expected to be equipped to face the next level of students education. This becomes important focus, since the boundaries between countries become more transparent and the competition is not merely takes place localy but globaliy since MEA is implemented.
\end{abstract}

\section{Keyword:}

\begin{abstract}
Abstrak
Pembelajaran sains merupakan proses pembelajaran sepanjang hayat sebagaimana belajar berbitung. Anak-anak dari segala jenis usia akan memperoleh manfaat dengan menganalisis keadaan-keadaan di sekitarnya yang mengadung unsur sains. Anak-anak perlu didorong agar memperoleb lebih banyak pengalaman sains di alam, kemudian menjelaskan peristiwa-peristiwa yang dilihatnya, menanyakannya, dan menganalisis cara peristiwa-peristiwa itu terjadi. Implementasi pembelajaran sains untuk anak usia dini dalam menghadapi MEA adalah dengan memasukkan enam keterampilan dasar sains ke dalam empat faktor penentu kemajuan suatu negara, yaitu inovasi, penguasaan jaringan melalui komunikasi, penguasaan teknologi, dan kekayaan sumberdaya alam. Adapun keenam keterampilan dasar sains yang perlu diajarkan kepada siswa adalab: pengamatan (observation), pengomunikasian (communication), pengklasifikasian (classification), pengukuran (measurement), penyimpulan (inference), dan peramalan (prediction). Keenam keterampilan di atas terintegrasi ketika seorang anak melakukan percobaan sederhana. Enam keterampilan dasar di atas sangat penting dalam kedudukannya sebagai keterampilan mandiri sebagaimana pentingnya ketika berkedudukan sebagai keterampilan terintegrasi. Keterampilan yang diasab sejak dini diharapkan akan menjadi bekal untuk menghadapi jenjang pendidikan siswa selanjutnya. Hal ini menjadi fokus penting mengingat batas-batas antar negara saat ini semakin transparan, persaingan tidak hanya terjadi secara lokal melainkan sudah bersifat global sejak dicanangkanya MEA.
\end{abstract}

Kata kunci: 


\section{PENDAHULUAN}

Pembelajaran sains untuk anak usia dini difokuskan pada pembelajaran mengenai diri sendiri, alam sekitar, dan gejala alam. Pembelajaran sains pada anak usia dini memiliki beberapa tujuan, diantaranya yaitu: (1) membantu pemahaman anak tentang konsep sains dan keterkaitannya dengan kehidupan sehari-hari, (2) membantu menumbuhkan minat pada anak usia dini untuk mengenal dan memperlajari benda-benda serta kejadian di lingkungan sekitarnya, (3) membantu anak agar mampu menerapkan berbagai konsep sains untuk menjelaskan gejala-gejala alam dan memecahkan masalah dalam kehidupan seharihari, (4) membantu anak usia dini untuk dapat mengenal dan memupuk rasa cinta kepada alam sekitar sehingga menyadari keagungan Tuhan Yang Maha Esa.

Namun, kenyataan yang terjadi pada umumnya dalam pembelajaran sains pada anak usia dini terjadi kesenjangan antara tujuan dan kenyataan dilapangan. Hal ini dapat dilihat dari metode guru yang masih menggunakan metode ceramah dan diskusi dalam praktik pembelajaran sains yang membuat anak banyak mendengar, duduk, dan diam, sehingga anak kurang diberikan kesempatan untuk memperoleh pengalaman nyata. Padahal hakikat pembelajaran sains adalah memberikan pengalaman yang menantang sehingga memfasilitasi rasa ingin tahu anak dengan menyuguhkan pembelajaran yang variatif, menyenangkan, serta untuk mengobservasi dan mengeksplorasi berbagai macam objek fisik, alam, atau kejadian-kejadian yang ada di lingkungan anak.

Disisi lain, anak masih mengalami kesulitan dalam mengembangkan keterampilan proses sains dikarenakan guru hanya menggunakan metode pemberian tugas. Anak hanya belajar dengan mendengarkan penjelasan guru kemudian anak mengerjakan tugas berupa lembar kerja anak. Pemberian tugas ini belum dapat dipahaminya karena anak tidak mengalami pengalaman langsung dalam suatu proses percobaan. Untuk mendapatkan pengalaman dalam proses percobaan diperlukan fasilitas dan metode yang mendukung melalui kegiatan yang dapat mencakup proses tersebut.
Pembelajaran sains pada anak usia dini sebaiknya dilakukan dengan metode pembelajaran yang dapat memberikan kesempatan kepada anak untuk aktif dalam mengeksplorasi berbagai ideide. Sebagai bagian dari mekanisme belajarnya, anak-anak perlu mengembangkan sendiri berbagai hipotesis dan secara terus-menerus membuktikannya. Melatih proses berpikirnya sendiri, mengamati apa yang terjadi, dan yang ditemukannya, kemudian mengajukan pertanyaan, serta merumuskan jawaban.

Pengenalan sains untuk anak usia dini lebih ditekankan pada proses daripada produk. Untuk anak prasekolah keterampilan proses sains hendaknya dilakukan secara sederhana sambil bermain. Kegiatan sains memungkinkan anak melakukan eksplorasi terhadap berbagai benda, baik benda hidup maupun benda tak hidup yang ada disekitarnya. Anak belajar menemukan gejala benda dan gejala peristiwa dari benda-benda tersebut.

Melalui pembelajaran sains anak sejak dini belajar untuk menggunakan lima inderanya untuk mengenal berbagai gejala benda dan gejala peristiwa. Anak dilatih untuk melihat, meraba, membau, merasakan dan mendengar. Semakin banyak keterlibatan indera dalam belajar, anak semakin memahami apa yang dipelajari. Anak memperoleh pengetahuan baru hasil penginderaanya dengan berbagai benda yang ada disekitarnya. Percobaan sederhana yang dilakukan untuk mengaplikasikan proses sains melatih anak menghubungkan sebab dan akibat dari suatu perlakuan. Kegiatan ini bisa melatih anak berpikir logis dan rasional.

Pendidikan anak usia dini merupakan suatu upaya pembinaan yang ditujukan kepada anak usia dini yang dilakukan dengan memberikan rangsangan pendidikan untuk membantu pertumbuhan dan perkembangan jasmani dan rohani. Ruang lingkup pada kurikulum Taman Kanak-kanak dan Raudlatul Afhtal mencakup bidang pengembangan pembiasaan dan bidang pengembangan kemampuan dasar yaitu berbahasa, kognitif, fisik atau motorik dan seni. Dalam bidang pengembangan kemampuan dasar kognitif bertujuan untuk mengembangkan kemampuan berpikir. 
Dengan mengembangkan kemampuan berpikir, anak diharapkan dapat mengolah perolehan belajar dan menemukan bermacam-macam alternatif pemecahan masalah yang dihadapi. Keterampilan tersebut akan berguna sebagai modal berpikir lanjut untuk menjawab berbagai tantangan di jenjang pendidikan yang lebih lanjut. Hal ini menjadi salah satu tuntutan mendesak seiring dengan dibukanya Masyarakat Ekonomi Asean (MEA). Persaingan pasar bebas akan terbuka lebar antar negara-negara anggota Asean. Persaingan bukan hanya terjadi pada sektor barang dan jasa melainkan juga kualitas sumberdaya manusia lewat masuknya pencari kerja asing. Sekolah sebagai salah satu instansi yang memiliki peran strategis mengembangkan sumber daya manusia harus bergerak cepat meningkatkan kualitas pendidikan. Siswa yang dulu hanya bersaing dengan teman sesesama, sekarang sudah harus siap bersaing teman dari luar negeri. Untuk itu siswa sejak usia dini perlu banyak mendapat ketrampilan dasar. Menyiapkan sumber daya manusia memang bukan pekerjaan mudah dan bisa dilakukan secara instant. Akan tetapi, apabila pendidikan bisa membekali siswa sejak usia dini, akan menghasilkan generasi yang memiliki rasa percaya diri dan motivasi untuk mengembangkan diri secara optimal sehingga mampu bersaing secara global.

\section{TINJAUAN PUSTAKA \\ Anak Usia Dini}

Anak usia dini atau anak prasekolah yang berusia 0-6 tahun merupakan individu yang proses pertumbuhan dan perkembangannya meliputi berbagai aspek dan dialami secara cepat dalam rentang kehidupan manusia. Menurut Steinberg, Hughes, dan Piaget, menjelaskan bahwa ciri-ciri perkembangan pada anak usia dini dibagi menjadi tiga. Perkembangan tersebut yaitu perkembangan fisik, perkembangan emosi-sosial, dan kemampuan mental.

\section{Ciri Fisik}

Anak dapat menggunakan bagian-bagian tubuhnya dengan spontan dan sangat aktif. Anak mampu mengendalikan dirinya dan mulai menyukai kegiatan keseharian yang mereka lakukan.

\section{Ciri Kebidupan Emosi-Sosial}

Pada kehidupan sosial, anak cenderung suka bermain dan membentuk kelompok. Pertemanan anan dimulai dengan anak-anak yang memiliki jenis kelamin sama lalu selanjutnya dengan yang berlainan. Anak menyesuaikan diri dengan lingkungannya secara cepat tapi beberapa anak ada yang kesulitan untuk bergaul dengan temannya ketika dia merasa tidak nyaman. Pada perkembangan emosi-sosial ini anak dapat dilatih untuk melakukan kebiasaan baik yang dapat menunjang kualitas hidupnya kelak.

\section{Ciri Kemampuan Mental}

Pada kemampuan mental ini anak senang belajar dengan imajinasinya yang tinggi. Anak menyukai kegiatan menggunting, menempel, dan melakukan hal-hal yang secara langsung dapat dilihat dan dipraktekan.

Dari karakteristik perkembangan anak usia dini diatas masa usia dini adalah masa yang tepat untuk penanaman pembelajaran yang berkesan, karena anak bersifat aktif dan memiliki rasa ingin tahu yang tinggi. Hal ini diharapkan pengalaman yang mereka terima akan benar-benar mereka bawa sampai dewasa nanti. Namun, perlu diperhatikan pula bahwa perkembangan anak tidak semuanya lancar. Semua dipengaruhi oleh berbagai faktor. Faktor tersebut bisa berasal dari diri anak yaitu anak memiliki kelainan fisik atau mental dan faktor lingkungan, utamanya lingkungan keluarga yang merupakan tempat pendidikan utama ketika anak berusia dini.

\section{Pembelajaran Sains}

Sains menurut Kilmer dan Hofman (1995) merupakan pengetahuan tentang fenomenafenomena tertentu, proses yang digunakan untuk mengumpulkan dan mengevaluasi informasi, dan sebagai bentuk adaptasi manusia pada lingkungan. Sains bukan hanya kumpulan fakta dan hafalan rumus saat belajar melainkan juga mencakup prinsip-prinsip, prosedur, dan sikap ilmiah. Sains juga dipandang sebagai suatu proses mencari tahu alam secara sistematis untuk mengetahui suatu pengetahuan.

Pembelajaran sains dalam pendidikan anak usia dini merupakan serangkaian kegitan 
belajar yang menyenangkan untuk menstimulus anak mengeksplorasi lingkungan mereka dan merefleksikan hasil pengamatan dan penemuan mereka. Cara ini juga merupakan pendekatan terpadu di mana anak-anak pada saat itu sedang berpikir dan membangun pemahaman dasar tentang dunia.

Banyak guru menganggap bahwa mereka kurang siap untuk mengajarkan sains pada anak usia dini (Wenner 1993). Hal ini mungkin diakibatkan karena kesalahpahaman bahwa sains membutuhkan bahan yang rumit dan sulit untuk dikuasai. Kesalahpahaman ini mengakibatkan banyak guru membelajarkan sains hanya secara teoritis sehingga dimensi sains sebagai proses dan sikap kurang mendapat perhatian.

\section{Proses Ilmiah}

Proses ilmiah adalah serangkaian proses keilmuan untuk memperoleh pengetahuan secara sistematis berdasarkan bukti fisis. Di dalam proses ilmiah berisi siklus membentuk hipotesis, pengumpulan data, mengkonfirmasi, membuat generalisasi, dan kemudian mengulangi siklus. Keterampilan dasar yang digunakan dalam proses ilmiah diantaranya adalah mengamati, mengklasifikasi dan membandingkan, mengukur, berkomunikasi, bereksperimen, mengaitkan, menyimpulkan, dan menerapkan. Karena menyimpulkan dan menerapkan membutuhkan pemikiran yang lebih abstrak, anak-anak tidak seharusnya diharapkan untuk memiliki keterampilan ini dalam arti formal, melainkan hanya hal-hal yang sifatnya esensial.

\section{Keterampilan Ilmiah Anak Usia Dini}

Anak-anak menemukan dan membangun pemahamanya tentang suatu hal dengan menerapkan proses-proses ilmu pengetahuan. Secara naluriah rasa ingin tahu anak memancing mereka untuk melakukan hal-hal yang berkaitan dengan proses ilmiah. Guru dapat memanfaatkan potensi ini untuk membimbing agar proses ilmiah yang dilakukan anak lebih terstruktur melalui kegiatan ilmiah, diskusi, memancing dengan pertanyaan-pertanyaan, dan berbagai strategi pengajaran lainnya. Melalui eksperimen memungkinkan anak memproses informasi baru yang ia dapatkan dari lingkungan sekitarnya.
Beberapa keterampilan yang paling sesuai untuk anak usia dini adalah mengamati, mengklasifikasi, membandingkan, mengukur, mengkomunikasikan, dan eksperimen. Mengasah keterampilan ini sangat penting untuk menghadapi kehidupan sehari-hari serta untuk studi masa depan anak. Beberapa keterampilan, yang berlaku untuk program ilmu anak usia dini, yaitu:

\section{Mengamati}

Melihat dan mengamati merupakan dua hal yang tidak sama. Guru perlu memberikan bimbingan dalam teknik observasi. Anakanak dapat didorong untuk memperhatikan tindakan yang memiliki informasi spesifik tertentu. Pengamatan tentu tidak terbatas hanya pada pengamatan visual, melainkan juga bisa melibatkan semua indera yaitu: melihat, mendengar, mencium, mencicipi, dan perasaan.

\section{Klasifikasi}

Klasifikasi adalah keterampilan proses dasar yang digunakan dalam mengorganisir informasi. Dalam rangka untuk mengklasifikasikan benda-benda atau informasi, anak-anak harus dapat membandingkan dan menyeimbangkan sifat beberapa benda. Anak-anak dapat mengklasifikasikan suatu benda berdasarkan karakteristik atau sifat-sifat tertentu misalnya berdasarkan fungsi, warna, atau bentuk.

Anak-anak harus dibimbing agar mampu untuk berpikir secara operasional konkret sebelum mereka dapat memikirkan sebuah benda termasuk dalam beberapa kategori sekaligus. Guru dapat mendorong anak untuk mengklasifikasikan benda-benda dan menjelaskan bagaimana benda telah dikelompokkan.

\section{Membandingkan}

Membandingkan adalah proses pemeriksaan objek atau peristiwa dalam hal kesamaan dan perbedaan. Ketrampilan ini biasanya melibatkan proses mengukur, menghitung, dan mengamati dengan seksama. Membandingkan penting setelah anak-anak mengamati suatu objek. Misalnya, setelah anak mengamati perilaku tikus dan marmut kemudian menentukan apa yang sama dan berbeda antara keduanya. Contoh lain anak 
membandingkan kelopak dan mahkota bunga mawar dengan bunga sepatu.

\section{Mengukur}

Pengukuran adalah keterampilan proses dasar yang diperlukan untuk mengumpulkan data. Pengukuran tidak hanya mengacu pada menggunakan ukuran standar. Anak-anak dapat mengukur makanan hamster dengan menggunakan sendok, memotong seutas tali yang sama panjangnya dengan tinggi tanaman kacang, atau menggunakan gelas untuk mengumpulkan air dalam ember kecil dan menghitung berapa gelas air yang dibutuhkan untuk memenuhi embernya.

\section{Komunikasi}

Anak-anak dapat didorong untuk berbagi pengamatan dan data data yang diperoleh melalui berbagai cara. Mereka dapat berbicara tentang temuan mereka, membuat catatan dalam bentuk gambar, atau narasi dalam rangka untuk berbagi informasi. Proses komunikasi sangat penting, karena dengan berkomunikasi anak-anak mulai memahami bagaimana cara mengutarakan pesan pada anak lain.

\section{Eksperimen}

Bereksperimen bukanlah proses baru untuk anak-anak. Mereka telah melakukan percobaan sejak mereka pertama kali mengambil mainan atau melemparkan semangkuk makanan. Dalam proses ilmiah, bereksperimen berarti mengendalikan satu atau lebih variabel dalam kondisi yang telah dimanipulasi. Guru dapat membantu anak-anak memikirkan kegiatan bermain mereka sebagai suatu percobaan dengan terampil mempertanyakan, mendorong anak-anak untuk merefleksikan tindakan mereka dan hasil dari tindakan mereka.

\section{Mengaitkan, Menyimpulkan, dan Menerapkan}

Anak-anak akan menggunakan keterampilan proses mengaitkan, menyimpulkan, dan menerapkan hanya dengan cara yang sangat informal. Pertama, mengaitkan merupakan proses menggambarkan secara abstrak dari bukti yang konkret. Misalnya, anak yang mengamati air yang membeku, mungkin anak tidak mampu mengaitkan pengamatan tersebut berkaitan dengan ide abtrak bahwa semua cairan akan menjadi padatan pada suhu tertentu.

Kedua, menyimpulkan merupakan kemampuan untuk menentukan hubungan sebab akibat atau penjelasan untuk fenomena yang prosesnya tidak langsung bisa diamati. Ketiga, menerapkan adalah menggunakan informasi dari pengalaman untuk menciptakan, membuat, memecahkan masalah baru, dan menentukan probabilitas. Anak-anak dapat terlibat dalam menerapkan pengetahuan ilmiah tapi tidak dalam pengertian analisis formal. Misalnya, anak-anak dapat mengamati perilaku air ketika dipanaskan hingga mendidih dan berubah menjadi uap, mereka dapat menerapkan pengamatan ini untuk diterapkan pada cairan lain (minyak goring atau madu) dan membuat prediksi tentang apa yang akan terjadi pada mereka dalam kondisi yang sama.

\section{Mengembangkan Sikap Ilmiah}

Dalam beberapa hal, sikap terhadap subjek atau kegiatan dapat sama pentingnya dengan subyek itu sendiri. Saah satu contoh adalah: individu yang tahu bahwa merokok bisa membunuh tetapi terus merokok, atau orang yang tahu bahwa mengenakan sabuk pengaman sangat meningkatkan peluang mereka untuk menghindari kecelakaan dan mencegah cedera, namun memilih untuk tidak memakainya. Sama halnya dengan sikap ilmiah.

\section{Rasa Ingin Tabu}

Perkembangan mental anak usia dini belum sampai pada tahapan mereka mampu membentuk sikap secara sistematis untuk melaksanakan suatu kegiatan. Akan tetapi mereka dapat mempraktekkan perilaku mencerminkan sikap ilmiah yang akan menumbuhkan kebiasaan jangka panjang.

Rasa ingin tahu dianggap salah satu sikap yang paling berharga yang dapat diproses oleh siapapun. Dibutuhkan individu yang memiliki rasa penasaran untuk melihat sesuatu dari sesuatu yang baru prespektif. Serangkaian pertanyaan panjang bisa timbul dari suatu pengamatan 
terhdap objek. Rasa ingin tahu merupakan dasar bagi ilmu pengetahuan merupakan sesuatu yang wajar untuk anak-anak. Mereka menggunakan semua indera dan energi mereka untuk "mencari tahu" tentang semua yang ditangkap oleh indra mereka. Namun, kenyataanya yang sering terjadi dalam proses pemelajaran formal kurang mengasah kemampuan eksplorasi dan interogasi anak sehingga mematikan karakteristik berharga ini. Salah satu cara yang bisa dilakukan untuk menumbuhkan kembali rasa ingin tahu anak ialah dengan memanfaatkan pengalaman belajar langsung atau penyelidikan siklus-siklus alam yang terjadi di sekitar mereka.

\section{Keraguan}

Anak-anak perlu didorong untuk mempertanyakan, bertanya-tanya, bertanya "mengapa", dan lebih teliti dalam menerima hasil dari hal-hal yang diamati. Pengalaman yang diperoleh dari observasi langsung terhadap suatu fenomena dan pengumpulan data, secara alami akan mendorong anak untuk mengeksplorasi situasi baru secara obyektif dan memiliki pemikiran yang terbuka.

\section{Pendekatan positif terbadap kegagalan dan citra diri}

Pendekatan positif terhadap kegagalan dan citra diri yang positif adalah sikap terkait erat. Anak perlu diberi keseempatan untuk mengajukan solusi mereka sendiri untuk suatu masalah yang dihadapi. Pada saat itu bisa jadi anak akan menemui jalan buntu, tetapi hal itu akan menjadikan anak memiliki pemikiran yang lebih kaya daripada langsung diarahkan pada jawaban yang benar. Jika anak terlalu banyak dikondisikan untuk meniru figur orang dewasa dalam mengidentifikasi dan memecahkan masalah, suatu saat mereka akan mengalami kesulitan jika dihadapkan pada permasalahan baru baik sebagai anak maupun sebagai orang dewasa.

\section{Pentingnya Sains Untuk Anak usia Dini}

Sejak lahir anak memiliki lebih kurang 100 miliar sel otak, sel-sel saraf ini harus rutin distimulasi dan didayagunakan agar terus berkembang jumlahnya. Pertumbuhan otak anak sangat dipengaruhi oleh bagaimana cara orangtua mengasuh dan asupan gizi serta stimulasi pendidikan. Dari aspek pendidikan, stimulan dini sangat diperlukan guna memberikan rangsangan terhadap seluruh aspek perkembangan anak yang mencakup penanaman nilai-nilai dasar, pembentukan sikap (disiplin dan kemandirian), dan pengembangan kemampuan dasar (berbahasa, motorik, kognitif, dan sosial).

Mengenalkan sains pada anak bukan berarti mengenalkan rumus-rumus. Mengenalkan sains pada anak harus sesuai dengan tahapan umur dan perkembangannya. Suasana harus dijaga supaya tetap menyenangkan, sehingga anak dalam kondisi ceria akan bertanya mengapa bisa demikian? Apakah kejadian selanjutnya? Dan sebagainya. Dalam situasi bermain itulah kita dapat melakukan eksperimen sains.

Sains melatih anak bereksperimen dengan melaksanakan beberapa percobaan, memperkaya wawasan anak untuk selalu ingin mencoba dan mencoba. Sehingga sains dapat mengarahkan dan mendorong anak menjadi seorang yang kreatif dan penuh inisiatif. Sains membiasakan anak-anak mengikuti tahap-tahap eksperimen dan tak boleh menyembunyikan suatu kegagalan. Artinya, sains dapat melatih mental positif, berpikir logis, dan sistematis. Di samping itu, dapat pula melatih anak bersikap cermat, karena anak harus mengamati, menyusun prediksi, dan mengambil keputusan.

\section{Masyarakat Ekonomi Asean (MEA)}

Di bukanya MEA tahun 2015 dapat dijadikan suatu momentum yang baik untuk Indonesia. Pertama, negara-negara di kawasan Asia Tenggara ini akan dijadikan sebuah wilayah kesatuan pasar dan basis produksi. Dengan terciptanya kesatuan pasar dan basis produksi maka akan membuat arus barang, jasa, investasi, modal dalam jumlah yang besar, dan skilled labour menjadi tidak ada hambatan dari satu negara ke negara lainnya di kawasan Asia Tenggara

Kedua, MEA akan dibentuk sebagai kawasan ekonomi dengan tingkat kompetisi yang tinggi, yang memerlukan suatu kebijakan yang meliputi competition policy, consumer protection, Intellectual Property Rights (IPR), taxation, dan E-Commerce. Dengan demikian, dapat 
tercipta iklim persaingan yang adil; terdapat perlindungan berupa sistem jaringan dari agen-agen perlindungan konsumen; mencegah terjadinya pelanggaran hak cipta; menciptakan jaringan transportasi yang efisien, aman, dan terintegrasi; menghilangkan sistem Double Taxation, dan; meningkatkan perdagangan dengan media elektronik berbasis online.

Ketiga, MEA pun akan dijadikan sebagai kawasan yang memiliki perkembangan ekonomi yang merata, dengan memprioritaskan pada Usaha Kecil Menengah (UKM). Kemampuan daya saing dan dinamisme UKM akan ditingkatkan dengan memfasilitasi akses mereka terhadap informasi terkini, kondisi pasar, pengembangan sumber daya manusia dalam hal peningkatan kemampuan, keuangan, serta teknologi.

Keempat, MEA akan diintegrasikan secara penuh terhadap perekonomian global. Dengan dengan membangun sebuah sistem untuk meningkatkan koordinasi terhadap negara-negara anggota. Selain itu, akan ditingkatkan partisipasi negara-negara di kawasan Asia Tenggara pada jaringan pasokan global melalui pengembangkan paket bantuan teknis kepada negara-negara Anggota ASEAN yang kurang berkembang. Hal tersebut dilakukan untuk meningkatkan kemampuan industri dan produktivitas sehingga tidak hanya terjadi peningkatkan partisipasi mereka pada skala regional namun juga memunculkan inisiatif untuk terintegrasi secara global.

Bagi Indonesia sendiri, MEA akan menjadi kesempatan yang baik karena hambatan perdagangan akan cenderung berkurang bahkan menjadi tidak ada. Pertukaran tenaga kerja professional juga merupakan salah satu $\mathrm{Hal}$ tersebut akan berdampak pada peningkatan eskpor yang pada akhirnya akan meningkatkan GDP Indonesia.

\section{PEMBAHASAN}

\section{Implementasi Pendidikan Sains dalam menghadapi MEA}

Dibukanya Masyarakat Ekonomi Asean (MEA) membuka peluang sekaligus tantangan bagi Indonesia. Sebagai salah satu negara yang kaya sumber daya alam menjadikan Indonesia berpotensi untuk memanfaatkan keunggulannya sebagai basis memperoleh keuntungan. Peluang ini terbuka lebar karena melalui MEA hambatan perdagangan antar negara-negara anggota Asean telah di tiadakan. Sebagai bagian dari masyarakat global tentu Indonesia harus siap berkompetisi. Terlebih kita sudah terikat dengan berbagai kesepakatan-kesepakatan global lainya, seperti Asean Free Trade Area (AFTA), World Trade Organization (WTO) dan Asia Pacific Economic Cooperation (APEC).

Namun di sisi lain MEA menjadi tantangan tersendiri untuk Indonesia karena Kesepakatan ini tak hanya berdampak pada sektor ekonomi, tapi juga sektor-sektor lainnya. Tak terkecuali di bidang pendidikan sebagai pilar utama pembangunan sumberdaya manusia. Di satu sisi MEA membuka peluang untuk meningkatkan pendidikan dengan memanfaatkan lembaga-lembaga pendidikan asing sebagai mitra kerja. Tapi, pada sisi lain menjadi kendala, sebab kekuatan akademik (academic strength) kita jauh tertinggal di bawah negara-negara yang pendidikannya sudah maju, seperti Finlandia, Kanada, dan Australia. Bahkan kualitas pendidikan kita masih di bawah negara-negara Asean, seperti Singapura, Brunei Darussalam, dan Malaysia.

Berdasarkan data dari Education For All (EFA) Global Monitoring Report, UNESCO tahun 2012, daya saing pendidikan Indonesia berada pada peringkat ke-64 dari 120 negara. Pada 2011, data Education Development Index (EDI) Indonesia mencapai 0,93 . Nilai itu menempatkan Indonesia di posisi ke-69 dari 127 negara di dunia. Demikian juga dengan hasil survei Programmme for International Student Assessment (PISA) pada tahun 2009 lalu bahwa Indonesia menduduki peringkat 62 dari 65 negara, dalam pemetaan kemampuan literasi sains. Hal ini menunjukan bahwa pemerintah dan semua stakebolder pendidikan harus berupaya lebih keras untuk meningkatkan kualitas pendidikan di Indonesia terutama pendidikan sain.

Tantangan besar untuk proses pendidikan ideal adalah tidak hanya mempersiapkan generasi bangsa mampu hidup hari ini, tapi mereka juga dibekali dengan kemampuan hidup di masa depan. Sebab, tantangan di era global semakin kompleks. Salah satu upaya tersebut adalah dengan jalan mengenalkan sains pada anak sejak 
usia dini. Sains merupakan ilmu yang sangat erat kaitanya dengan proses mencari tahu tentang alam sekitar secara sistematis, menemukan, bersikap ilmiah dan mengkomunikasikan sebagai salah satu aspek penting kecakapan hidup.

Pengasahan kemampuan komunikasi dalam sains bisa menjadi bekal kehidupan seharihari serta untuk studi masa depan anak. Selain untuk berinteraksi dengan lingkungan sekitar, keterampilan komunikasi dapat berguna untuk mengetahui kehidupan yang lebih luas. Dalam organisasi keterampilan berkomunikasi berguna untuk mengefektifkan setiap fungsi manajemen. Dalam konteks pasar bebas MEA kemampuan komunikasi merupakan salah satu faktor penting untuk bernegosiasi dan menjalin relasi.

Pembelajaran sains melatih anak menggunakan lima inderanya untuk mengenal berbagai gejala benda dan gejala peristiwa. Anak dilatih untuk melihat, meraba, membau, merasakan dan mendengar. Semakin banyak keterlibatan indera dalam belajar, maka semakin komplek pemahaman anak. Anak juga dilatih bereksperimen dengan melaksanakan beberapa percobaan sederhana. Hal ini tentu akan memperkaya wawasan anak dan merangsang rasa ingin tahu untuk selalu ingin mencoba sesuatu yang baru sehingga sains dapat mengarahkan dan mendorong anak menjadi seorang yang kreatif, inovatif, dan penuh inisiatif.

Percobaan sederhana yang dilakukan juga melatih anak menghubungkan sebab dan akibat dari suatu perlakuan. Sains membiasakan anakanak mengikuti tahap-tahap eksperimen dan tak boleh menyembunyikan suatu kegagalan. Artinya, sains dapat melatih mental positif, berpikir logis, dan urut (sistematis). Di samping itu, sains dapat pula melatih anak bersikap cermat, karena anak harus mengamati, menyusun prediksi, dan mengambil keputusan.

Selain melalui percobaan sederhana, sains juga bisa diajarkan pada anak usia dini menggunakan multimedia interaktif. Hal ini dikarenakan beberapa objek sains cukup kompleks dan sulit untuk langsung sajikan dari alam. Penggunaan multimedia juga digunakan untuk memanipulasi objek dari ukuran aslinya. Objek yang terlalu besar bisa disajikan lebih ringkas sedangkan objek yang terlalu kecil bisa ditampilkan dalam ukuran yang lebih besar. Beberapa objek sains juga terlalu berbahaya jika langsung diajarkan secara langsung, contohnya harimau atau letusan gunung berapi. Meskipun multi media interaktif bisa memberi pengalaman belajar yang sangat representatif dan menyenangkan guru tetap harus melakukan bimbingan agar tidak terjadi miss konsepsi pemahaman anak.

Pembelajaran sains pada anak usia dini sangat penting untuk memberikan bekal ilmu pengetahuan kepada anak tentang alam dan segala isinya. Pembelajaran sains tidak hanya membina domain kognitif anak, melainkan membina aspek afektif dan psikomotor secara seimbang. Lebih jauh diharapkan dengan mengembangkan pembelajaran sains yang memadai (adequate) akan menumbuhkan kreativitas dan kemampuan berpikir kritis yang semuanya akan sangat bermanfaat bagi aktualisasi dan kesiapan anak menjadi generasi berkualitas untuk menghadapi perannya yang lebih luas dan kompleks pada masa akan datang.

Mengacu pada faktor penentu kemajuan suatu negara, inovasi (45\%), penguasaan jaringan/ networking melalui komunikasi $(25 \%)$ dan penguasaan teknologi $(20 \%)$ merupakan tiga faktor berturutturut yang paling mempengaruhi kemajuan negara. Sedangkan kekayaan sumberdaya alam hanya $(10 \%)$ dari seluruh aspek. Melihat porsi perbandingan tersebut maka sudah sepantasnya pendidikan kita harus lebih menekankan pada tiga kemampuan di atas. Dengan menerapkan pembelajaran sains sejak usia dini sangat sejalan dengan upaya peningkatan kemajuan negara. Karena inovasi, teknologi, dan komunikasi adalah aspek-aspek yang sangat erat kaitanya dalam proses pembelajaran sains.

Menyiapkan sumber daya manusia memang bukan pekerjaan mudah dan bisa dilakukan secara instant. Akan tetapi, apabila pendidikan kita (guru dan sekolah) bisa membekali siswa dengan kemampuan tersebut, lulusan pendidikan kita akan memiliki rasa percaya diri dan motivasi untuk mengembangkan diri secara optimal sehingga mampu bersaing secara global. Dengan demikian, pendidikan kita memiliki andil besar dalam menyiapkan sumberdaya yang siap menghadapi MEA 2015 maupun persaingan global. 


\section{PENUTUP \\ Kesimpulan}

Sains adalah proses sepanjang hayat sebagaimana belajar berhitung. Anak-anak dari segala jenis usia akan memperoleh manfaat dengan menganalisis keadaan-keadaan di sekitarnya yang mengadung unsur sains. Anakanak perlu didorong agar memperoleh lebih banyak pengalaman sains di alam, kemudian menjelaskan peristiwa-peristiwa yang mereka lihat, menanyakannya, dan menganalisis cara peristiwa-peristiwa itu terjadi. Jika kita tidak menginteraksikan sains kepada anak-anak sejak dini, maka sama artinya kita mencetak anak-anak yang sukar menganalisis peristiwa sains. Dengan demikian, ketika kita menginginkan anak-anak kita memiliki kinerja yang baik saat duduk di jenjang sekolah yang lebih tinggi, maka sains mesti kita ajarkan sejak taman kanak-kanak.

Dalam pengajaran sains, ada enam buah keterampilan proses dasar yang perlu diajarkan kepada murid. Keterampilan-keterampilan proses merupakan bagian-bagian yang membentuk landasan metode-metode ilmiah. Keenam keterampilan tersebut yaitu: pengamatan (observation); pengomunikasian (communication); pengklasifikasian (classification); pengukuran (measurement); penyimpulan (inference); dan peramalan (prediction).

Keenam keterampilan di atas terintegrasi ketika seorang anak melakukan percobaan sederhana. Enam keterampilan dasar di atas sangat penting dalam kedudukannya sebagai keterampilan mandiri sebagaimana pentingnya ketika berkedudukan sebagai keterampilan terintegrasi. Ketrampilan yang diasah sejak dini diharapkan akan menjadi bekal untuk menghadapi jenjang pendidikan siswa selanjutnya. Hal ini menjadi fokus penting mengingat batas-batas antar negara saat ini semakin transparan, persaingan tidak hanya terjadi secara local melainkan sudah bersifat global sejak dicanangkanya MEA 2015

\section{Saran}

Bagi pengembang pembelajaran sains pada anak usia dini, hendaknya pahami terlebih dahulu tujuan sains secara komprehensif dan karakteristik perkembangan anak usia dini untuk setiap tahapan usia, kemudian tuangkan dalam rencana pembelajaran yang operasional dengan menerapkan konsep bermain yang menyenangkan.

Gunakan multi media dalam pembelajaran sains, untuk menghindari rasa jenuh, bosan pada anak, serta mempertahan perhatian anak untuk tidak berpaling pada objek lain

\section{DAFTAR PUSTAKA}

Brewer, Jo Ann. 2007. Introduction to Earlychilhood Education, Preschool Through-Primary Grades 6th Edition.

Click, Phyllis \& Kim Karkos. 2007. Administration of Programs for Young Children 7th Edition. Amerika: Express

E. Grossman Klause Ph D, Karin Grossman Ph D\& Everett Waters Ph D. 2005. Attachment from Infancy to Adulthood" The Major Longitudinal Studies". New York: The Guilford Press

E. Berk, Laura. 2001. Awakening Children's Minds. New York: Oxford University Press

Eliason, Claudia \& Loa Jenkins. 2007. A Preactical Guide to Early Chilhood Curriculum 8th Edition. Kong Seoul Singapore Taipei Tokyo: Amerika.

Panitia Sertifikasi Guru Unesa. 2012. Materi: Pendidikan dan Latihan Profesi Guru. Surabaya: Universitas Negeri Surabaya

Nugraha, Ali. (2005). Pengembangan Pembelajaran Sains Pada Anak Usia Dini. Jakarta: Depdiknas.

News.detik.com. (2Agustus 2014). RI Terendah di PISA. di akses 27 Maret 2015, dari http:/ / news.detik.com/read/2014/02/08/15312 4/2491125/10/1/ri-terendah-di-pisa-wnaindonesian-kids-dont-know-how-stupidthey-are

tribunnews.com. (24 Desember 2014). Tantangan Pendidikan Menuju MEA 2015. di akses tanggal 27 Maret 2015, dari http://banjarmasin.tribunnews. com/2014/12/24/tantangan-pendidikanmenuju-mea-2015?page $=3$ 